\title{
AIR POLLUTION TOLERANCE INDEX OF Mangifera indica PLANT SPECIES GROWING IN THE GREATER DHAKA REGION, BANGADESH
}

\author{
Sadia, H. E., F. Jeba, A. T. M. M. Kamal ${ }^{1}$ and A. Salam \\ Department of Chemistry, University of Dhaka, Dhaka-1000, Bangladesh; ${ }^{1}$ Department of Soil, Water \\ and Environment, University of Dhaka, Dhaka-1000, Bangladesh
}

\begin{abstract}
Air pollution tolerance index (APTI) of the mango (Mangifera indica) leaves growing in the greater Dhaka region, Bangladesh was studied. Leaf samples were collected in winter season from both roadsides and residential locations of different parts of greater Dhaka region. The APTI values of the leaves were calculated from the total chlorophyll content (TCC), ascorbic acid concentration, relative water content (RWC), and pH of the leaf extract. Determined APTI values were compared with Particulate Matter $\left(\mathrm{PM}_{2.5}\right)$ values in each sampling location. TCC and ascorbic acid concentration were determined with a UVVisible spectrophotometer. TCC values varied between 0.25 and $1.10 \mathrm{mg} / \mathrm{g}$ with an average of $0.66 \mathrm{mg} / \mathrm{g}$. The average concentration of ascorbic acid was $2.21 \mathrm{mg} / \mathrm{g}$ (values ranging from 0.33 to $3.24 \mathrm{mg} / \mathrm{g}$ ) and the RWC varied from $81.5 \%$ to $97.4 \%$. Moreover, $\mathrm{pH}$ values of the leaf extracts were found acidic (4.48-5.78). The average APTI values varied depending on the locations with a total average of 10.1. However, the average APTI value in the residential area (10.5) was slightly higher compared to roadsides (9.70) indicating the existence of high-level pollutions at the roadsides. The highest APTI value was observed in Dhaka city sampling location (10.6) where the lowest value was found in Narayangonj (9.70). APTI values showed a strong correlation with particulate matter concentrations $\left(\mathrm{PM}_{2.5}\right)$. These results suggest that Mangifera indica is very sensitive to the air pollutants.
\end{abstract}

Key words: Urban air pollution; Air pollution tolerance index; Ascorbic acid; Chlorophyll; Relative water content.

\section{INTRODUCTION}

Air pollution has a significant impact on human health, climate change and on ecosystem as a whole. Ecosystem itself is a natural process or system of interaction between abiotic and biotic factors in an area of the biosphere. All living organisms including plants, animals, microbes and other ecological complexes are the parts of an ecosystem. These are the factual components of an ecosystem in both the rural and urban areas. When one of the interacting factors gets interrupted, the whole ecosystem is affected. Plants are the most important determinant of the survival of life on earth. Plants can reduce air pollution through absorption and accumulation of pollutants on the enormous surface of leaves (Joshi and Swami 2009, Rawat and Banerjee 1996). So, plants are the initial receptors of air pollution and serve as collectors of many air-bone particulates and pollutants (Liu and Ding 2008). It can also cause injury in leaf, stomatal damage, the decrease of photosynthetic process, distract membrane permeability, growth reduction and yield of sensitive plants (Tiwari et al. 2006). However, sulfur dioxide, oxides of nitrogen, carbon dioxide and suspended particulate matters are absorbed on the leaves and may cause a reduction in the concentration of photosynthetic pigments, e.g. chlorophyll and carotenoids and directly affect plant productivity (Joshi and Swami 2007). Gradual decrease of chlorophyll and associated yellowing of leaves is one of the most common consequences of pollution (Joshi and Swami 2007). These changes in plant morphology and physiology are location specific depending on the nature of pollutions.

Air pollution tolerance index (APTI) is very important to understand the impact of air quality in plants. It is the inherent quality of plants which counters air pollution affects. Some biochemical parameters, such as total chlorophyll concentration (TCC), ascorbic acid concentration, relative water content (RWC) and pH of the leaf extracts are measured to determine the APTI value of a plant species 
using the formula $A P T I=\frac{([A(T+P)]+R)}{10}($ Singh and Rao 1983). Different plant parameters were used in many previous studies for APTI calculation (e.g., Singh 1989, Joshi and Swami 2007) as one parameter may not be enough for the evaluation. Therefore, ascorbic acid, water content, TCC, $\mathrm{pH}$ along with visible foliar injury, leaf conductance, and membrane permeability of the leaf extract were determined for understanding the impact of air pollution and its mechanism in plants (Singh, 1989). The mechanism between the pollutants and these parameters has not been fully understood yet. However, Sing and Rao (1983) used the formula to determine APTI value which we used in our study. Singh and Rao (1991) reported that the $\mathrm{pH}$ dependent reducing power of ascorbic acid protected chloroplast from $\mathrm{SO}_{2}$ induced pollution and the enzymes of the $\mathrm{CO}_{2}$ fixation cycle and chlorophyll from inactivation. Thus, the part of the above equation, $[\mathrm{A}(\mathrm{T}+\mathrm{P})]$ represents the $\mathrm{SO}_{2}$ sensitivity and $\mathrm{R}$ term indicates the capacity of cell membrane to maintain its permeability under polluted environment. Plants with low indices are generally sensitive to air pollution and vice versa. On the basis of these indices, evergreen plants of $M$. indica are classified into three groups as sensitive (less than 12), intermediate (13-16), moderately tolerant (16-20) and tolerant (greater than 20) according to the value of APTI (Singh and Rao 1991).

Plants can also be used as bio indicator depending on the resistance of the plants to air pollutants (Lakshmi et al. 2009). Babu et al. (2013) determined the air pollution tolerance index (APTI) of seven plants at both polluted and background locations. All the plants were found to be sensitive to the air pollutants (APTI values ranging from 7.38 to 10.1 in the polluted site, and 6.44 to 9.60 in background site). Kuddus et al. (2011) estimated APTI values of seven economically important plant species growing in the urban-industrial region of Allahabad, India. They reported that $M$. indica (APTI value of 18.5) can be considered as a tolerant species and the Artocarpus species (APTI value 8.75) was the most sensitive to air pollutants. Rafiq and Kumawat (2016) studied the effect of dust from cement industries on various parts of the apricot tree growing at different distances from the cement industrial belt Khrew, Kashmir, India. The chlorophyll and carotenoid content, $\mathrm{pH}$ of leaf wash, $\mathrm{pH}$ of leaf extract, and length of leaf were reduced due to the dust exposure. Tsega and Prasad (2014) worked on APTI and anticipated performance index (API) of five roadsides plant species using biological parameters.

Air pollution is a serious problem in the large cities of Bangladesh. Rapid industrialization and economic growth are continuously introducing new pollutants to the atmosphere. Coal burning in the brick kilns, rice mills and power plants, fossil fuel burning, traffic, industrial and residential emissions is contributing to the ambient particulate matters in Dhaka and other major cities in Bangladesh. Peoples are using cow dung, woods, dry leaves, rice husk and straw, jute stick, bagasse, bamboo, etc. at their cooking stoves in most of the rural areas of Bangladesh. These diverse air pollutions have a serious impact on plants. Regarding the impact of air pollution on plants in Bangladesh, there is no such study. Therefore, it stands essential to study the sensitivity of plants to air pollutions to avoid their extinction. To understand the impact of the air pollution on the species of $M$. indica, we envisaged to determine the air pollution tolerance index (APTI) based on ascorbic acid concentration, TCC, RWC and pH of leaf extract.

\section{Sample collection}

\section{MATERIAL AND METHODS}

The fresh matured leaf samples of Mangifera indica were collected between January and February 2015 from roadsides and residential locations in the urban Dhaka region (Dhaka City Centre, Gazipur, Narayangonj, Narsingdi and Savar) in Bangladesh (Fig. 1).

The leaves were collected manually from the bottom of the tree crown, about 8-10 feet above from the soil. The matured leaf samples were collected from nearby branches of tree in winter season. Winter is assumed to be the season of comparatively higher air pollution. Thus, we aimed to work in this season. The collected leaves were neither too young nor too old. They were free from any types of 
visible diseases of leaf and fungal attack. All the plants had almost the same ecological condition with respect to light, water, soil, pollutant exposure. They were collected fresh and analyzed as early as possible to avoid dryness. The leaf samples were extracted with standard solvents and measured the TCC, ascorbic acid concentration, RWC, and $\mathrm{pH}$. Air pollution tolerance index (APTI) was calculated to study the sensitivity of the plant.

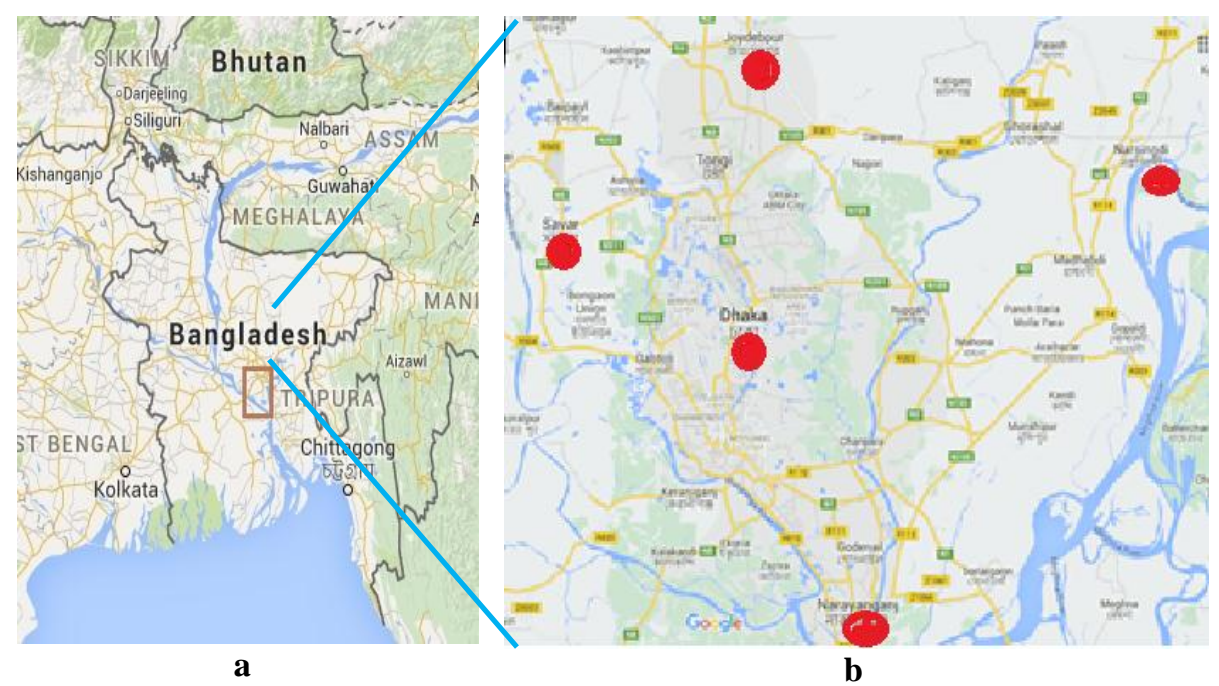

Fig. 1 a. Map of Bangladesh; b. Red circles are the exact sampling locations in urban Dhaka, Bangladesh (Dhaka city Centre, Gazipur, Narayangonj, Narsingdi and Savar).

The major sources of pollutants on these areas were automobile exhaust and domestic heating for cooking. The roadside areas are bus stoppage and busy market sides. Residential sites consisted of concrete buildings and some are made of bamboo. The overall description of the sampling sites is given below (Table 1).

Table 1. Characteristics of the locations studied in greater Dhaka region.

\begin{tabular}{|c|c|}
\hline Sampling site & $\begin{array}{l}\text { Location Characteristics } \\
\end{array}$ \\
\hline Dhaka & $\begin{array}{l}23.8105^{\circ} \mathrm{N}, 90.3372^{\circ} \mathrm{E} \\
\text { Hub of all activities. There are educational institutes, offices, residential buildings, } \\
\text { parks, few industries, busy traffic roads, vehicles mostly driven by CNG or petrol. }\end{array}$ \\
\hline Gazipur & $\begin{array}{l}24.0958^{\circ} \mathrm{N}, 90.4125^{\circ} \mathrm{E} \\
\text { Along with remote rural areas, there are many garment factories, pharmaceuticals, } \\
\text { railway station. }\end{array}$ \\
\hline Narayangonj & $\begin{array}{l}23.7147^{\circ} \mathrm{N}, 90.5636^{\circ} \mathrm{E} \\
\text { Industrial area and highway roads connecting to the capital. Oil factories, chemica } \\
\text { industries, cement and waving factories are very common there. }\end{array}$ \\
\hline Savar & $\begin{array}{l}23.8820^{\circ} \mathrm{N}, 90.2808^{\circ} \mathrm{E} \\
\text { Very near from the capital. Along with university, it is familiar for many footwear, } \\
\text { plastic, chemical industries. }\end{array}$ \\
\hline Narsingdi & $\begin{array}{l}24.1344^{\circ} \mathrm{N}, 90.7860^{\circ} \mathrm{E} \\
\text { Plastic and polymer industries, Jute industries, textile, chemical industries are very } \\
\text { common with its remote rural area. }\end{array}$ \\
\hline
\end{tabular}




\section{Meteorology of Bangladesh}

The climate in Bangladesh is characterized by high temperatures, excessive humidity, and distinct seasonal variations in precipitation. The seasons of Bangladesh include pre-monsoon (March-May), monsoon (June-September), post-monsoon (October-November), and winter (December-February). The average winter temperature varies from $4{ }^{\circ} \mathrm{C}$ to $25^{\circ} \mathrm{C}$, and the average summer temperature varies from $24^{\circ} \mathrm{C}$ to $36^{\circ} \mathrm{C}$. The highest relative humidity occurs in July (99\%), and the lowest in December (36\%). Moderately higher temperatures were generally observed during the afternoon. Light precipitation occurs during March and April. The average meteorological conditions in the greater Dhaka have been given by Salam et al. (2003). The average temperature during hot, humid summer is $30^{\circ} \mathrm{C}$ to $40^{\circ} \mathrm{C}$, in a cool rainy season is $28^{\circ} \mathrm{C}$ to $35^{\circ} \mathrm{C}$ and during cool, dry winter is $10^{\circ} \mathrm{C}$ to $18^{\circ} \mathrm{C}$. Wind direction in Dhaka city is mainly from west and south-west direction at pre-monsoon and north and north-west at winter.

\section{Total chlorophyll content determination (TCC)}

Chlorophyll content was determined by using the method of Singh et al. (1991). This method was also used by Kuddus et al. (2011), Veni et al. (2014) and Nwadinigwe (2014) for chlorophyll content determination. Five hundred $\mathrm{mg}$ of leaf samples was ground with a mortar and pestle in small quantity $(10.0 \mathrm{ml})$ of $80 \%$ acetone. The absorbance of the filtered extract was measured with a UV-Visible spectrophotometer (Model UV-1800, Shimadzu, Japan) at $645 \mathrm{~nm}$ and $663 \mathrm{~nm}$. The following equation was used for the TCC determination.

$$
\text { Total chlorophyll content }\left(\frac{m g}{g}\right)=(20.2 \times A 645+8.02 \times \mathrm{A} 663) \times \frac{V}{1000 \times W}
$$

$$
\begin{aligned}
& \text { Where, } \mathrm{A} 645=\text { Absorbance at } 645 \mathrm{~nm}, \\
& \mathrm{~A} 663=\text { Absorbance at } 663 \mathrm{~nm}, \\
& \mathrm{~V}=\text { Total volume of the extract, } \\
& \mathrm{W}=\text { Weight of leaf materials in gram. }
\end{aligned}
$$

\section{Ascorbic acid determination}

Ascorbic acid was determined by using the method of Keller and Schwager (1977). Five hundred $\mathrm{mg}$ of fresh mango leaf samples were homogenized with $20 \mathrm{ml}$ of extracting solution preparing $500 \mathrm{mg}$ oxalic acid and $75 \mathrm{mg}$ EDTA in $100 \mathrm{ml}$ of distilled water. 2,6-dichlorophenol indophenol (DCPIP) (3 $\mathrm{mg}$ in $100 \mathrm{ml}$ distilled water) was added to one $\mathrm{ml}$ of the above filtrate solution. The absorbance of the mixture was recorded at $520 \mathrm{~nm}$ (Es). After measuring the absorbance of the mixture, few drops of ascorbic acid was added to the mixture to bleach the pink color. After bleaching, the absorbance was recorded again at the same wavelength (Et). The absorbance of DCPIP solution was also recorded at 520 $\mathrm{nm}$ (Eo). The concentrations of the ascorbic acid in Mangifera indica leaf samples were calculated using the following equation.

$$
\begin{aligned}
& \text { Ascorbic acid }\left(\frac{m g}{g}\right)=\frac{[E 0-(E s-E t)] \times V}{W \times V 1 \times 1000} \\
& \text { Where, } \mathrm{W}=\text { Weight of the fresh leaf taken }(\mathrm{g}), \\
& \mathrm{V}_{1}=\text { Volume of the supernatant solution }(\mathrm{ml}), \\
& \mathrm{V}=\text { Total volume of the solution }(\mathrm{ml}) .
\end{aligned}
$$


The value of [Eo - (Es - Et)] was determined from following calibration curve. The calibration curve was prepared by using different known concentration of ascorbic acid solutions following the above method (Fig. 2).

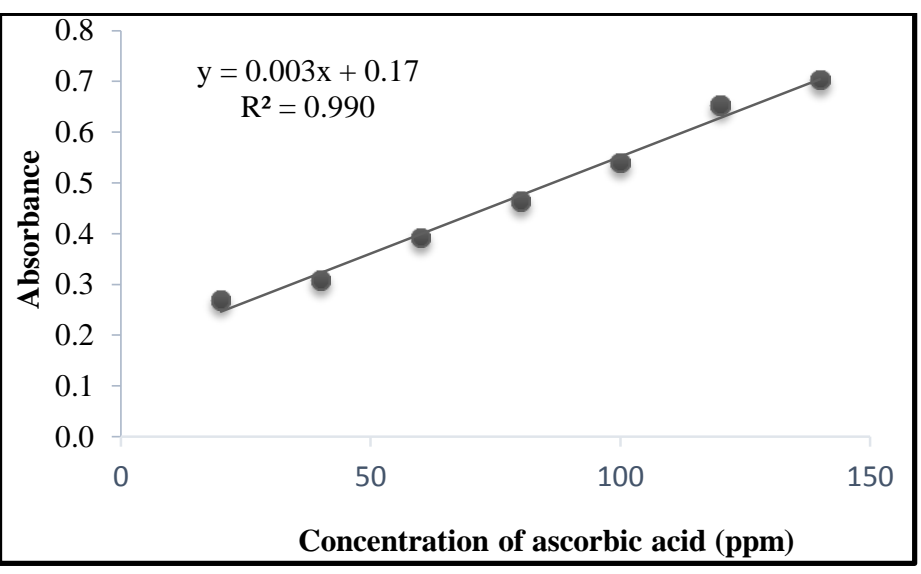

Fig. 2 Calibration curve for the determination of ascorbic acid concentration in leaf extracts.

\section{Relative water content ( $R W C$ ) determination}

RWC was determined by using the method of Sivakumaran and Hall (1978). Individual leaf of Mangifera indica was excised and weighed immediately (initial weight) with an analytical balance (Model XB 120A, Precisa Gravimetric AG, Dietikon, Switzerland). Leaves were dipped into water in a beaker for about six hours. The leaves were then blotted and weighed (saturated weight). Then the leaves were dried at $80^{\circ} \mathrm{C}$ for 16.0 hours and the dry weight was again recorded. The RWC was calculated by using the following equation.

$$
R W C(\%)=\frac{\text { Initial weight }- \text { Dry weight }}{\text { Saturated weight }- \text { Dry weight }}
$$

\section{pH determination}

The $\mathrm{pH}$ of the leaf extract was determined by homogenizing about one $\mathrm{g}$ sample with $10 \mathrm{ml}$ of deionized water. The $\mathrm{pH}$ of the suspension was measured with a digital $\mathrm{pH}$ meter (Model $\mathrm{pH} 211$, Hanna Instrument, Germany).

\section{Air pollution tolerance index (APTI) determination}

The APTI of Mangifera indica leaf was calculated by using following equation, which was developed by Singh and Rao (1983). The equation has been given as follows:

$$
A P T I=\frac{[A(T+P)]+R}{10}
$$

Where, $\mathrm{A}$ is the ascorbic acid content in the leaf in $\mathrm{mg} / \mathrm{g}$ dry weight, $\mathrm{T}$ is total chlorophyll content of leaf in $\mathrm{mg} / \mathrm{g}$ dry weight, $\mathrm{P}$ is the $\mathrm{pH}$ of the leaf extract, and $\mathrm{R}$ is the percentage (\%) $\mathrm{RWC}$ of the leaf.

\section{$P M_{2.5}$ concentration measurement in sampling sites}

The particulate matter $\left(\mathrm{PM}_{2.5}\right)$ concentration in the air of the sampling sites was measured by Aerocet (531S) with a flow rate of $2.83 \mathrm{~L} / \mathrm{min}$, a battery operated, handheld mass monitor or particle counter and 
completely portable unit. This unit provides particle counts or mass PM measurements as stored datalogged values, real-time networked data, or printed results.

\section{RESULTS AND DISCUSSION}

Air pollution impacts on tree of different parts of greater Dhaka region were studied. A low APTI value has observed in greater Dhaka region due to the high air pollution. The detail of results has given in Table 2.

Table 2. Summary of the measured parameters of Mangifera indica leaves at different roadsides and residential locations in urban Dhaka, Bangladesh with APTI values.

\begin{tabular}{|c|c|c|c|c|c|c|c|}
\hline Locations & Types & $\begin{array}{c}\text { Water } \\
\text { content }(\%)\end{array}$ & $\mathbf{p H}$ & $\begin{array}{l}\text { Chlorophyll } \\
\text { content }(\mathrm{mg} / \mathrm{g})\end{array}$ & $\begin{array}{c}\text { Ascorbic } \\
\text { acid (mg/g) }\end{array}$ & $\begin{array}{l}\text { APTI } \\
\text { value }\end{array}$ & $\begin{array}{c}\text { Average } \\
\text { APTI }\end{array}$ \\
\hline \multirow{2}{*}{ Narayangonj } & Residential & 88.02 & 5.78 & 0.25 & 2.94 & 10.57 & 9.70 \\
\hline & Roadside & 86.35 & 5.48 & 0.41 & 0.33 & 8.83 & \\
\hline \multirow{2}{*}{ Narsingdi } & Residential & 94.00 & 5.48 & 0.88 & 1.12 & 10.11 & 10.10 \\
\hline & Roadside & 90.96 & 4.48 & 0.40 & 2.15 & 10.09 & \\
\hline \multirow{2}{*}{ Dhaka } & Residential & 97.41 & 5.55 & 1.10 & 2.31 & 11.28 & 10.52 \\
\hline & Roadside & 87.09 & 5.01 & 0.76 & 1.82 & 9.76 & \\
\hline \multirow{2}{*}{ Savar } & Residential & 83.51 & 5.42 & 0.70 & 2.80 & 10.06 & \\
\hline & Roadside & 81.52 & 5.12 & 0.64 & 2.54 & 9.62 & 9.84 \\
\hline \multirow{3}{*}{ Gazipur } & Residential & 84.85 & 5.52 & 0.96 & 2.80 & 10.30 & 10.25 \\
\hline & Roadside & 82.79 & 5.46 & 0.48 & 3.24 & 10.20 & \\
\hline & Average & 87.65 & 5.33 & 0.66 & 2.21 & 10.1 & \\
\hline
\end{tabular}

\section{Total Chlorophyll Content (TCC)}

The total average chlorophyll content in Mangifera indica leaves was $0.66 \mathrm{mg} / \mathrm{g}$. Average chlorophyll content of the leaves in the residential area $(0.78 \mathrm{mg} / \mathrm{g})$ was 1.5 times higher than the roadsides $(0.54 \mathrm{mg} / \mathrm{g})$. Narayangonj, the high polluted location, had the lowest amount of TCC, whereas Dhaka had the highest value of TCC. The variation of the TCC between the roadsides and residential areas at different sampling locations in the greater Dhaka has been given in Fig. 3.

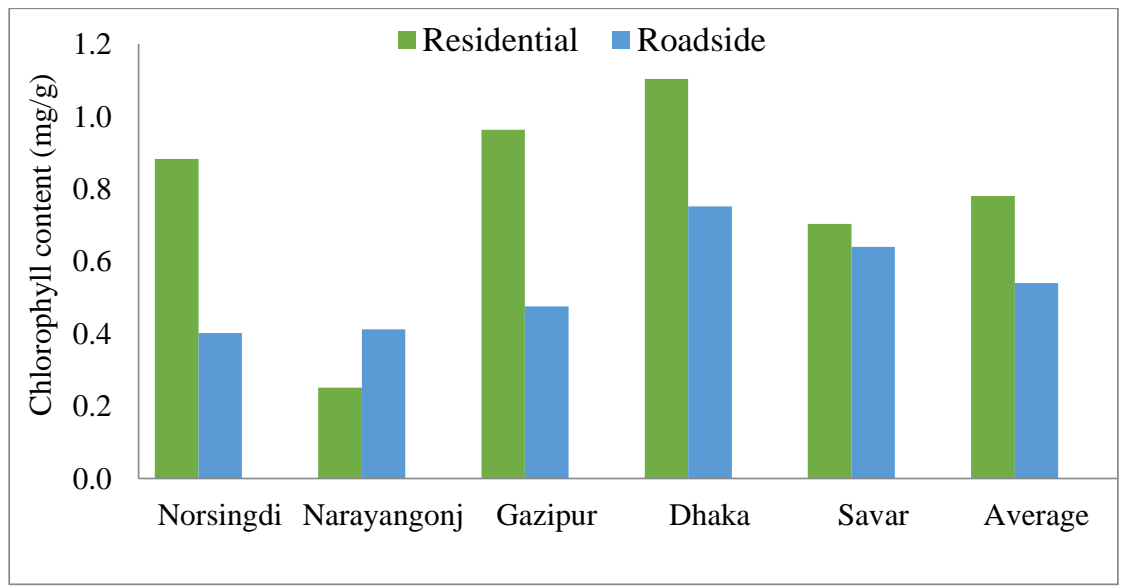

Fig. 3. Total chlorophyll content (mg/g) in Mangifera indica leaf samples at the different roadsides and residential locations in urban Dhaka, Bangladesh.

\section{Ascorbic acid content}

Total average of the ascorbic acid content was found to be $2.21 \mathrm{mg} / \mathrm{g}$ in mango leaves in the greater Dhaka region. The amount of ascorbic acid was the highest in the samples of Gazipur, whereas the 
lowest value was in Narayangonj. Narsingdi and Narayangonj showed an almost similar value of the ascorbic acid content. Moreover, ascorbic acid concentrations were higher in the residential areas (2.39 $\mathrm{mg} / \mathrm{g})$ than the roadsides $(2.02 \mathrm{mg} / \mathrm{g})$. The variation of the ascorbic acid content between the roadsides and residential areas at different sampling locations in the greater Dhaka has been given in Fig. 4.

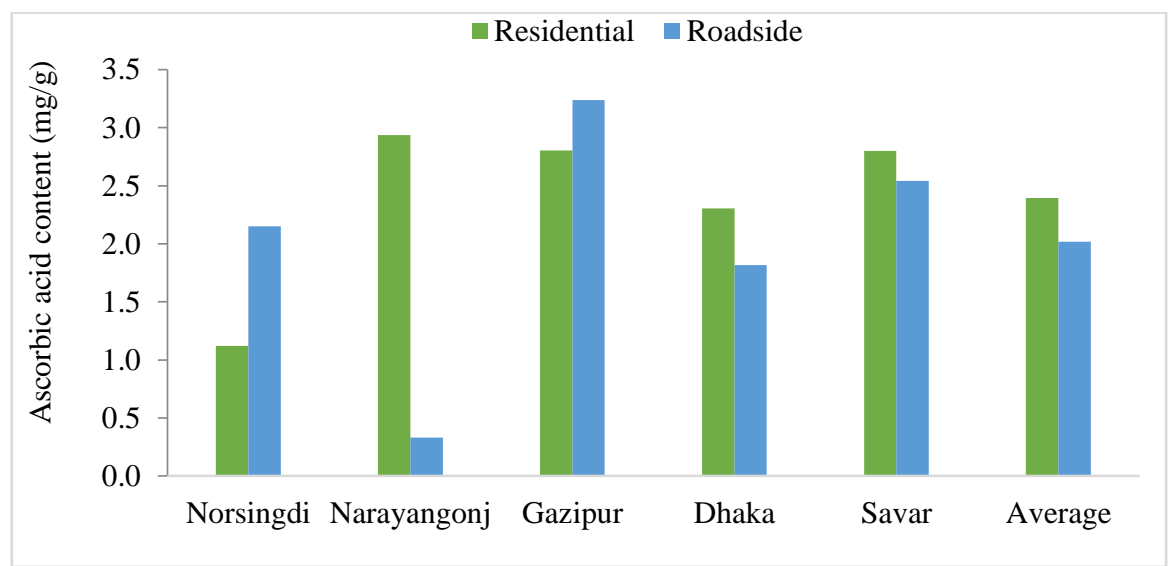

Fig. 4. Ascorbic acid content (mg/g) in Mangifera indica leaf samples at the different roadsides and residential locations in urban Dhaka, Bangladesh.

\section{Relative water content ( $R W C$ )}

The RWC in mango leaves was found to be $87.7 \%$ (on average) in greater Dhaka. However, RWC value was higher in residential areas $(89.6 \%)$ than the roadsides $(85.8 \%)$. The samples collected from Dhaka city and Narsingdi have the highest water content and lowest in Savar among these five sampling locations. The variation of the RWC between different roadsides and residential locations in the greater Dhaka region has been given in Fig. 5.

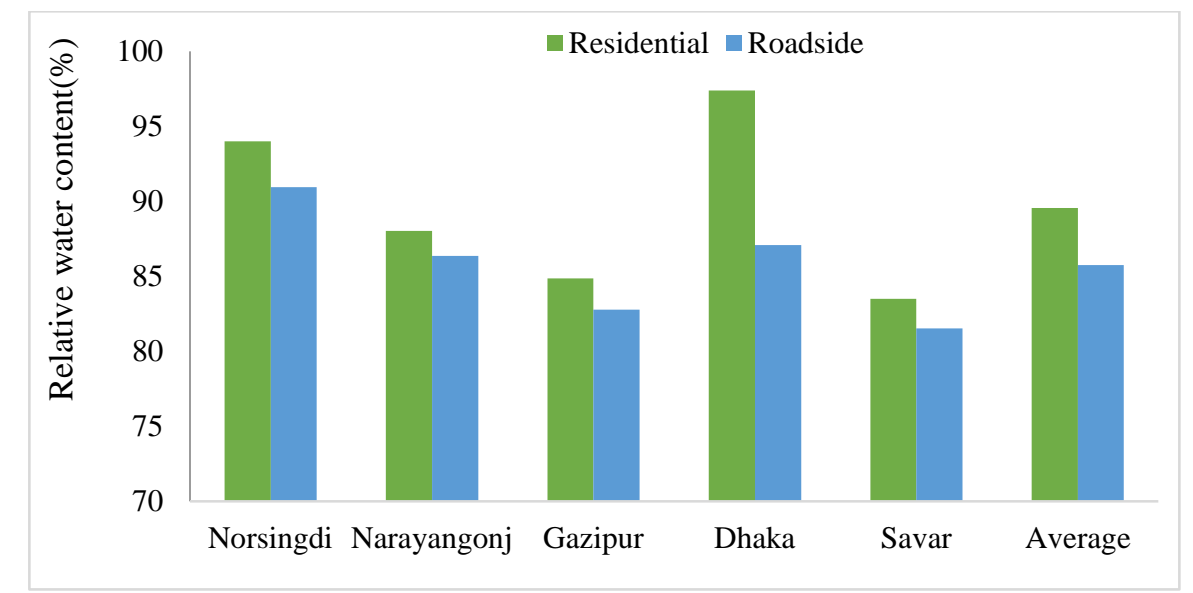

Fig. 5. Relative water content (\%) in Mangifera indica leaf samples at the different roadsides and residential locations in urban Dhaka, Bangladesh.

$p H$

The $\mathrm{pH}$ values of mango leaf extracts were almost similar (on average 5.33) at these five sampling locations in Dhaka region. All the $\mathrm{pH}$ values were acidic. A slightly higher $\mathrm{pH}$ value was observed in the residential area (5.55) than the roadsides (5.11). The variation of the $\mathrm{pH}$ values has been given in Fig. 6. 
The amount of TCC was decreasing with the increase of air pollution. Deposition of suspended particulate matters on the leaf surface might be responsible for the decrease in concentration of chlorophyll. Oxy radicals produced from reactions with $\mathrm{SO}_{2}, \mathrm{NO}_{2}$, and $\mathrm{O}_{3}$ damaged chlorophyll and the membrane of the leaf (Shakaki et al. 1983). $\mathrm{SO}_{2}$ also act as a potential bleaching and strong reducing agent. It is soluble in water and produces sulfurous acid. This acid ionizes to form $\mathrm{H}^{+}$and removes $\mathrm{Mg}^{2+}$ from chlorophyll a converting it to phaeophytin a. Thus, the chlorophyll content decreases due to the destruction of the structure in more polluted areas.

$$
\begin{aligned}
& \mathrm{H}_{2} \mathrm{SO}_{3} \rightarrow \mathrm{HSO}_{3}{ }^{-}+\mathrm{H}^{+} \\
& \mathrm{HSO}_{3}{ }^{-} \rightarrow \mathrm{SO}_{4}{ }^{2-}+\mathrm{H}^{+} \\
& \text {Chlorophyll }+2 \mathrm{H}^{+} \rightarrow \text { Phaeophytin }+\mathrm{Mg}^{2+}
\end{aligned}
$$

Nwadinigwe (2014) reported slightly higher chlorophyll content (about $0.78 \mathrm{mg} / \mathrm{g}$ ) in Nigeria. Veni et al. (2014) found about $0.20 \mathrm{mg} / \mathrm{g}$ chlorophyll content in the leaves of mangoes in India. Kuddus et al. (2011) found a relatively higher value $(12.3 \mathrm{mg} / \mathrm{g})$ than all the values listed in Table 3 . Pollutant resistivity of the plants increases with the amount of ascorbic acid concentration (Lima et al. 2000). Cytotoxic radicals are generated, when oxidative pollutants penetrate into the leaves. Ascorbic acid is consumed during the removal process (Pandey and Agrawal 1994). In the current study, the ascorbic acid concentration in the roadside leaves was lower than residential (up to $15.0 \%$ ) presumably due to the high pollution stress. This decrease in ascorbic acid concentration deteriorates the plant's defense system. The ascorbic acid content in leaves was about 2.19 times higher in India (Kuddus et al. 2011) and 27.6 times lower in Nigeria (Nwadinigwe 2014) compared to Dhaka, Bangladesh (Table 3).

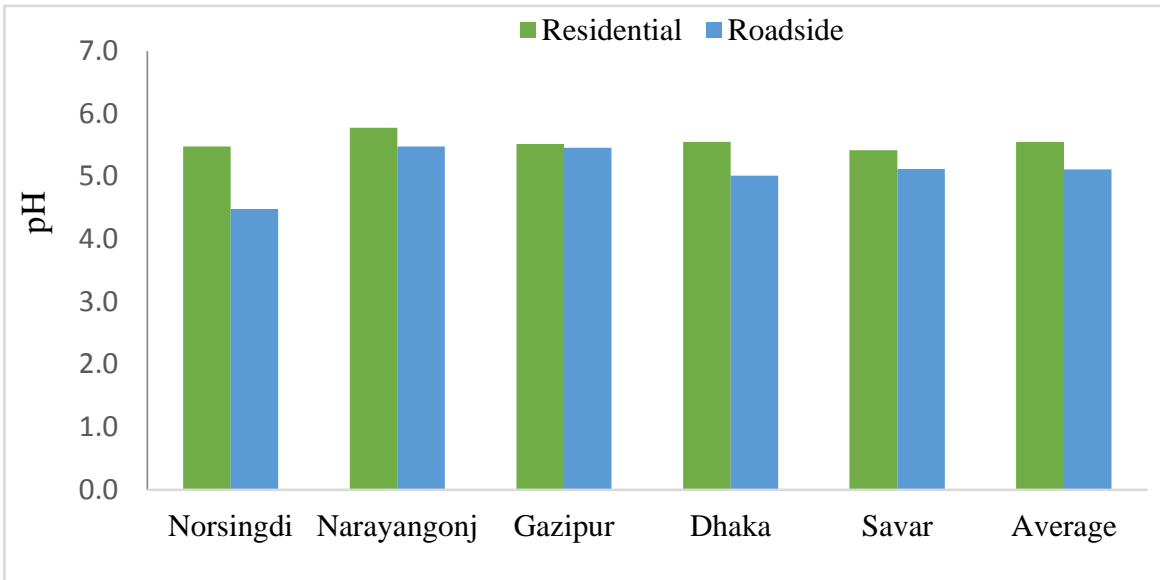

Fig. 6. $\mathrm{pH}$ values in Mangifera indica leaf samples at the different roadsides and residential locations in urban Dhaka, Bangladesh.

The plants with high RWC are tolerant to the polluted environments. The transpiration rate is lower with the lower water content under stressed condition. Air pollutants increase cell permeability and cause loss of water and dissolved nutrients from plant tissue. Early senescence of leaf occurs due to the increasing pollution. Dhaka city and Narsingdi were relatively less dry and less polluted than the other three sampling loscations in greater Dhaka. Mango leaves in Savar showed low water content due to the high pollutions from the garments and manufacturing industries. The RWC value in India $(89.86 \%)$ (Kuddus et al. 2011) was slightly higher than the current study. Nwadinigwe (2014) found very low water content in Nigeria (3.72\%). 
Acidic $\mathrm{pH}$ (on average 5.33) indicates the presence of SOx and NOx in the ambient air (Swami et al. 2004). Diffusion of $\mathrm{SO}_{2}$ through stomata, gaseous $\mathrm{SO}_{2}$ dissolves in water to form sulfites, bisulfate and other ionic species with the generation of protons, have a great impact on the plant cellular $\mathrm{pH}$. The $\mathrm{pH}$ change towards acidic range observed in most plant species is due to the entry of $\mathrm{SO}_{2}$ into leaf mesophyll tissue. The plants with lower $\mathrm{pH}$ are more susceptible and $\mathrm{pH}$ around 7.0 is tolerant (Singh and Verma 2007). Hence, mango leaves are very sensitive to pollutants in both the roadsides and residential areas in greater Dhaka. The slightly higher $\mathrm{pH}$ value (5.70) was observed in Nigeria (Nwadinigwe 2014) than that of Dhaka. Neutral or slightly basic pH was found by Veni et al. (2014) (8.50) and Kuddus et al. (2011) (7.40) in India (Table 3).

Table 3. Comparison of different environmental parameters affecting Mangifera indica in the present study with previous studies in Nigeria and India.

\begin{tabular}{lcccc}
\hline & Current study (2015) & Nwadinigwe (2014) & Veni et al. (2014) & Kuddus et al. (2011) \\
\hline & Bangladesh & Nigeria & India & India \\
\hline${ }^{\mathrm{a}} \mathrm{TCC}(\mathrm{mg} / \mathrm{g})$ & 0.66 & 0.78 & 0.20 & 12.28 \\
${ }^{\mathrm{b}} \mathrm{AAC}(\mathrm{mg} / \mathrm{g})$ & 2.21 & 0.08 & 1.33 & 4.84 \\
$\mathrm{pH}$ & 5.33 & 5.70 & 8.50 & 7.40 \\
$\mathrm{pH}$ & 87.65 & 3.72 & 46.00 & 89.86 \\
${ }^{\mathrm{R}} \mathrm{R} C(\%)$ & 10.10 & 3.92 & 5.50 & 18.51 \\
${ }^{\mathrm{d}}$ APTI & & & & \\
\hline
\end{tabular}

Overall results for APTI have been given in the following Fig. 7 and Fig. 8. The mango leaves in roadsides areas showed lower APTI than the residential locations. Dhaka city had the highest APTI value (10.52) among all the sampling locations in the current study indicating a lower level of pollutions. A lower APTI value (9.70) was observed in Narayangonj, which indicates the sensitivity of the mango leaves towards the air pollution in this area. Irrespective of the variation in the APTI values and sampling locations, Mangifera indica is showing sensitivity towards the air pollutants in greater Dhaka.

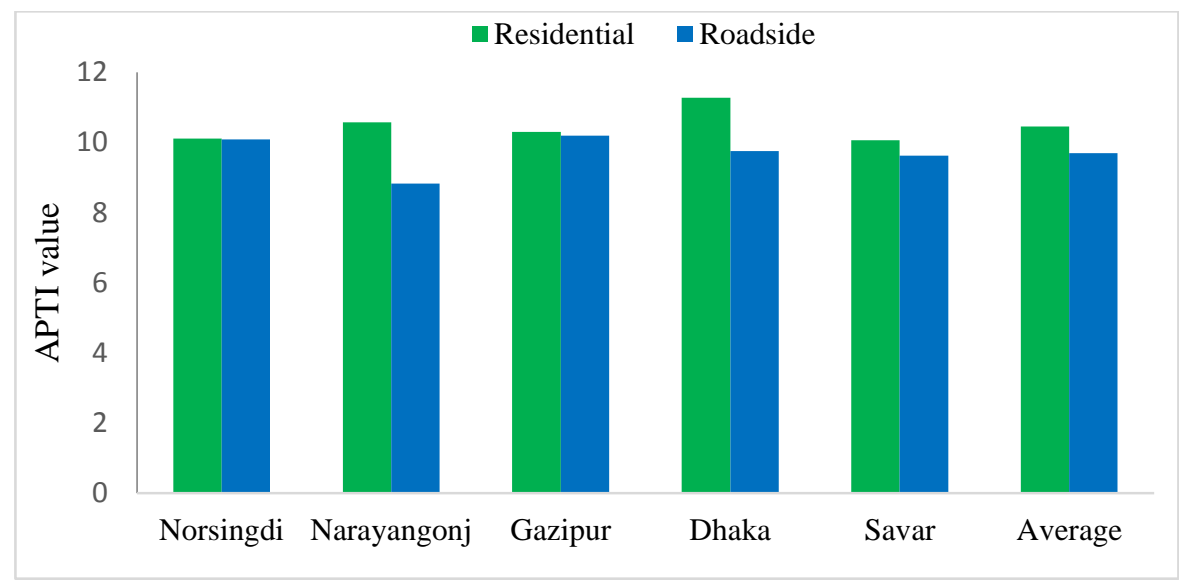

Fig. 7. APTI values in Mangifera indica leaf samples at the different roadsides and residential locations in urban Dhaka, Bangladesh.

The APTI values have a strong correlation $\left(\mathrm{r}^{2}=0.9506\right)$ with $\mathrm{PM}_{2.5}$ in all the sampling locations. Most polluted areas with high $\mathrm{PM}_{2.5}$ values have low APTI values and vice versa (Fig. 8). Brick kiln emission and long-range transport along with traffic and construction activities may have a significant 
contribution to the elevated concentrations of atmospheric particulate matters in Dhaka city as well as nearby locations. The emissions from brick kilns are also expected to be contributed to the high-level pollution during this winter sampling period as brick kilns are operating only during winter.

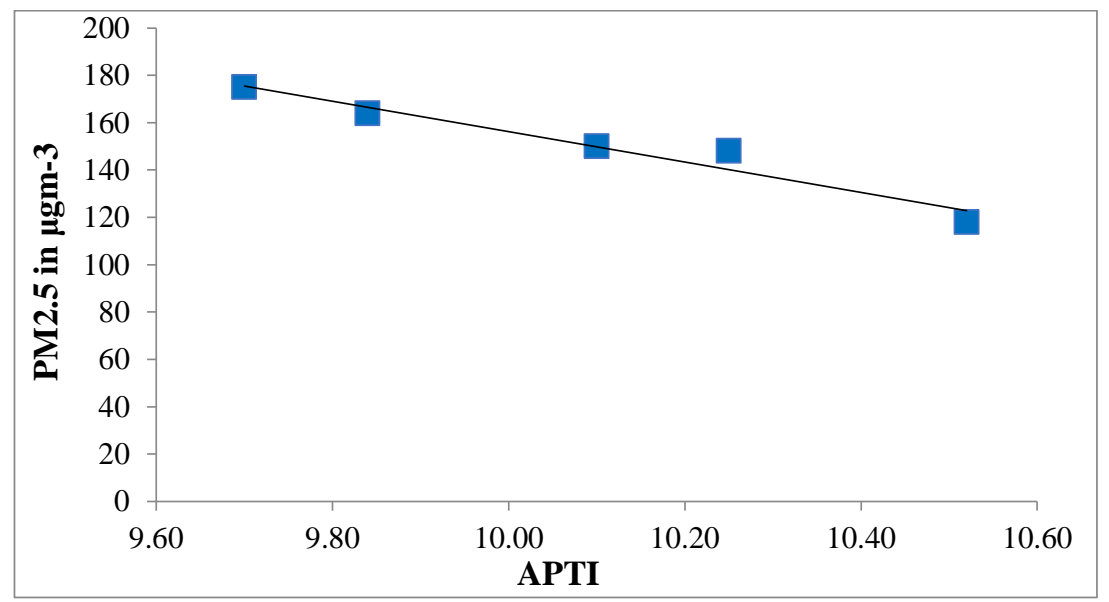

Fig. 8. The correlation between air pollution tolerance index (APTI) and $\mathrm{PM}_{2.5}$ in five sampling locations in greater Dhaka region.

However, plants are continuously exposed to the air pollution leading to an accumulation of pollutants in their system. It alters the nature of the leaves and makes them more sensitive to the pollutants. The APTI values of the $M$. indica leaves collected from different roadsides and residential locations in greater Dhaka were found to be low. It shows the sensitivity of the mango leaves to the pollution irrespective of the sampling locations in greater Dhaka region. The APTI values of $M$. indica leaves were in the range of 9.70-10.52. The total average chlorophyll content in plant species was $30.0 \%$, and the ascorbic acid concentrations were $15.0 \%$ higher in the residential locations than that of the roadsides. The $\mathrm{pH}$ of the leaf extracts (5.33) was acidic, and the $\mathrm{RWC}$ was $87.7 \%$. There were no significant differences between roadsides and residential values of the determined parameters as well as APTI values. These results suggest that Mangifera indica is very sensitive to the air pollutants. The concerned authorities should take measures for saving mango tree from air pollution and be concerned about choosing the tree species for afforestation.

\section{ACKNOWLEDGEMENTS}

Authors acknowledge the help of Maksudur Rahman, Shohel Wahid, Salma Akter during sampling. Thanks also to Mr. Md. Halimur Rahman for help with chemical analysis.

\section{REFERENCES}

Babu, G. B., S. N.Parveen, K. N. Kumar and M. S. Reddy. 2013. Evaluation of air pollution tolerance indices of plant species growing in the vicinity of cement industry and Yogi Vemana University campus. J. Adv. Chem. Sci. 2: 16-20.

Joshi, P. C. and A. Swami. 2009. Air pollution induced changes in the photosynthetic pigments of selected plant species. J. Environ. Biol. 30: 295-298.

Joshi, P. C. and A. Swami. 2007. Physiological responses of some tree species under roadside automobile pollution stress around the city of Haridwar, India. Environmentalist. 27: 365-374. 
Keller, T. and H. Schwager. 1977. Air pollution and ascorbic acid. European J. Forest Pathol. 7: 338350.

Kuddus, M., R. Kumari and P. W. Ramteke. 2011. Studies on air pollution tolerance of selected plant in Allahabad city, India. J. Environ. Res. Manag. 2: 42-46.

Lakshmi, P. S., K. L. Sravanti and N. Srinivas. 2009. Air pollution tolerance index of various plants growing in industrial areas. The Ecoscan. 2: 203-206.

Lima, J. S., E. Fernandes and W. Fawcett. 2000. Mangifera indica and Phaseolus vulgaris in the bioindicator of air pollution in Bahia, Brazil. Ecotoxicol. Environ. Safety. 46: 275-278.

Liu, Y. J. and H. Ding. 2008. Variation in air pollution tolerance index of plants near a steel factory: Implication for landscape plant species selection for industrial areas. WSEAS Trans. Environ. Dev. 4: 24-32.

Nwadinigwe, A. O. 2014. Air pollution tolerance index of some plants around an industrial complex in Enugu state, Nigeria. African J. Biotech. 13(11): 1231-1236.

Pandey, J. and M. Agrawal. 1994. Evaluation of air pollution phytotoxicity in a seasonally dry tropical urban environment using three woody perennials. New Phytologist. 126: 53-61.

Rafiq, R. and D. M. Kumawat. 2016. The impact of Cement Industry Pollution on Physio-morphological attributes of Apricot tree (Prunus armeniaca) around industrial belt Khrew, Kashmir, India. Int. Archive App. Sci. Tech. 7(1): 1-5.

Rawat, J. and S. Banerjee. 1996. Urban forestry for improvement of the environment. Energy Environ. Monitor. 12: 109-116.

Shakaki, T., N. Kondo and K. Sugahara. 1983. Breakdown of photosynthetic pigments and lipids in spinach leaves with ozone fumigation: Role of activated oxygen. Physiol. Plant. 59: 28-34.

Salam, A., H. Bauer, K. Kassin, S. M. Ullah and H. Puxbaum. 2003. Aerosol chemical characteristics of a mega-city in Southeast Asia (Dhaka-Bangladesh). Atmospheric Environ. 37: 2517-2528.

Singh, S. K. 1989. Study of plants in relation to $\mathrm{SO}_{2}$ pollution abatement. $\mathrm{Ph}$. D. thesis. Banaras Hindu University, Varanasi.

Singh, S. K., D. N. Rao, M. Agrawal, J. Pande and D. Narayan. 1991. Air pollution tolerance index of plants. J. Environ. Manag. 32: 45-55.

Singh, S. K. and D. N. Rao. 1983. Evaluation of plants for their tolerance to air pollution. Proceedings of the Symposium on Air Pollution Control., pp. 218-224.

Singh, S. N. and A. Verma. 2007. Phytoremediation of Air Pollutants. In: S. N. Singh and R. D. Tripathi (eds.). A review in Environmental Bioremediation Technology. Springer, Berlin Heidelberg. 1: 293-314.

Sivakumaran, S. and M. A. Hall. 1978. Effect of age and water stress in endogenous levels of plants growth regulators in Euphorbia lathyrus. J. Exp. Bot. 29: 195-205.

Swami, A., D. Bhatt and P. Joshi. 2004. Effects of automobile pollution on sal (Shorea robusta) and rohini (Mallotus phillipinensis) at Asarori, Dehradun. Himalayan J. Environ. Zool. 18: 57-61.

Tiwari, S., M. Agrawal and F. M. Marshall. 2006. Evaluation of ambient air pollution impact on carrot plants at a sub urban site using open top chambers. Environ. Monitoring Assess. 119: 15-30. 
Tsega, Y. C. and A. D. Prasad. 2014. Variation in air pollution tolerance index and anticipated performance index of roadside plants in Mysore, India. J. Environ. Biol. 35: 185-190.

Veni, K., Marimuthu and K. Lavannya. 2014. Air pollution tolerance index of plants a comparative study. Int. J. Pharm. Pharm. Sci. 6(5): 320-324. 